\title{
Sex Differences in Renal Function: Participation of Gonadal Hormones and Prolactin
}

\author{
Adriana Franco-Acevedo ${ }^{1}$ (D), Raquel Echavarria ${ }^{2}(\mathbb{D})$ and Zesergio Melo ${ }^{2, *(D)}$ \\ 1 Centro de Investigación Biomédica de Occidente, Instituto Mexicano del Seguro Social, \\ Guadalajara 44340, Mexico; ady_francoa@hotmail.com \\ 2 CONACyT-Centro de Investigación Biomédica de Occidente, Instituto Mexicano del Seguro Social, \\ Guadalajara 44340, Mexico; rechavarria@conacyt.mx \\ * Correspondence: zcmelo@conacyt.mx
}

Citation: Franco-Acevedo, A.;

Echavarria, R.; Melo, Z. Sex

Differences in Renal Function:

Participation of Gonadal Hormones and Prolactin. Endocrines 2021, 2, 185-202. https://doi.org/10.3390/ endocrines2030019

Academic Editor:

Alessandro Genazzani

Received: 6 May 2021

Accepted: 23 June 2021

Published: 5 July 2021

Publisher's Note: MDPI stays neutral with regard to jurisdictional claims in published maps and institutional affiliations.

\begin{abstract}
Kidney pathophysiology is influenced by gender. Evidence suggests that kidney damage is more severe in males than in females and that sexual hormones contribute to this. Elevated prolactin concentration is common in renal impairment patients and is associated with an unfavorable prognosis. However, PRL is involved in the osmoregulatory process and promotes endothelial proliferation, dilatation, and permeability in blood vessels. Several proteinases cleavage its structure, forming vasoinhibins. These fragments have antagonistic PRL effects on endothelium and might be associated with renal endothelial dysfunction, but its role in the kidneys has not been enough investigated. Therefore, the purpose of this review is to describe the influence of sexual dimorphism and gonadal hormones on kidney damage, emphasizing the role of the hormone prolactin and its cleavage products, the vasoinhibins.
\end{abstract}

Keywords: kidney; renal physiology; gender; hormones; prolactin; vasoinhibins

\section{Introduction}

The prevalence of renal disease has increased globally in recent years. The sex and gender-specific disparities are remarkable. In 2016, the Global Burden of Disease Study reported that there were more than 7 million people with impaired kidney function [1], of which 4 million were women and 3 million were men [1]. This gender disparity was also reported by Fraser et al., who found that from 2007 to 2017, the global prevalence of CKD increased around $28 \%$ in women compared to an increase of $25 \%$ in men [2]. These differences in sex are manifested in response to several factors. The kidneys respond to differences in age, genetics, race, and hormones. These hormonal responses contribute to the hypothesis that female hormones exert a protective role contrary to that of male hormones. However, it is difficult to compare epidemiological studies because most of them are carried out in very large and diverse populations, particularly with regard to aspects such as age. In this review we address information from studies that analyze and compare kidney function in both sexes, and we will explore specific differences in the physiological and pathological aspects.

\section{Morphological and Physiological Renal Differences between Genders}

The kidneys are responsible for eliminating waste products from the body, controlling blood pressure, and the homeostasis of hormones, water, and solutes [3]. This organ is made up of cortical and medullar zones, containing its functional units, the nephrons. Each nephron is composed of a glomerular and a tubular segment. Along the tubular segment in the membrane are many transporters and channels involved in ion exchange.

Structural, hemodynamic, and physiological aspects display significant differences among genders [4]. Renal hemodynamic differences occur in female rats. Renal plasma flow 
and vascular kidney resistance are higher in females when compared to their male counterparts, further suggesting that a lower glomerular capillary pressure could partly explain sex-dependent protection in females by reducing the risk of suffering a hyperfiltrationinduced injury [5]. Nevertheless, structural discrepancies remain controversial. Miletic et al. described bigger kidney sizes in men compared to women [6]. This study was conducted with a cohort of 1852 participants that reported higher total kidney volume in men [7]. A study in postmortem kidney specimens found larger glomerular volume, body surface area, and kidney weight in males compared to females [8]. Munger et al. described more glomeruli per gram of kidney weight in female rats [5]. However, this association did not translate to humans [8]. In murine models, male kidneys had larger mitochondria and more lysosomes in the proximal segment, possibly due to the higher metabolic demands required for reabsorption and secretion $[9,10]$.

Kidney volume directly correlates with glomerular filtration rates (GFR) [11]. Creatinine clearance, the gold standard to evaluate kidney function, is influenced by gender. A prospective cohort of living kidney donors reported higher GFR in men compared to women [12]. James et al. measured the serum creatinine levels and urinary creatinine clearance. The results indicated that women presented fewer levels of urinary creatinine than men. These differences persisted even after the determinations were adjusted for corporal weight. Men had 33\% more urinary creatinine by weight and better creatinine clearance than women [13]. The higher excretion of creatinine is associated with more significant muscle mass related to meat intake, but this relationship is debatable [13]. Perucca et al. analyzed various independent studies associated gender and urine osmolarity with diverse living conditions. The results showed a higher tendency to produce more concentrated urine in men than women [14]. In the process of urine formation, approximately $99 \%$ of water and solutes are reabsorbed, and 1\% is excreted [15]. Solute reabsorption presents sexual dimorphism and is widely considered to be higher in males [16]. This effect might be due to the androgen stimulation of angiotensin II and increased sodium-hydrogen exchanger 3 (NHE3), a transporter responsible for sodium reabsorption along the proximal tubule $[17,18]$. The NHE3 transporter is also involved in ammonium secretion. Harris et al. found that better ammonium clearance in female mice was associated with a higher expression of proteins related to ammonia metabolism and transport [19]. Veiras et al. determined a structural kidney transporter profile between sexes in rodents. In this study, sodium transporters were poorly expressed in the proximal nephron and higher in the distal nephron in females than in males [16]. This female-associated pattern could be a mechanism of adaptation to fluid retention designed for pregnancy and lactation [16]. In age-fertile women, urate concentration is lower in serum and higher in renal clearance than in men [20], increasing risk of developing gout in males [21]. URAT1, a transporter localized in the apical membrane of the proximal tubules and responsible for the urate reabsorption pathway, is less expressed in female mice and could be involved in these effects [21].

As mentioned above in this review, physiological attributes such as renal solute excretion reveal gender-related disparities [22]. In turn, these variations impact the risk of kidney stone formation [23]. Although, the formation of kidney stones shows a significant intra-individual variation, it is known that it occurs more frequently in men than in women [23]. However, as a result of modifications in contemporary lifestyle, diet, and chronic kidney disease, the risk of suffering this disease in women has increased $[24,25]$. One of the most accepted explanations for this disparity is that considering a more alkaline $\mathrm{pH}$ optimizes the solubility of some salts and uric acid [26,27], under physiological conditions, women have a higher urinary $\mathrm{pH}$ than men.

\section{Role of Gender in Disease-Related Kidney Injury}

\subsection{Acute Kidney Injury}

Kidney damage has multiple etiologies. Acute kidney injury (AKI) is characterized by an imbalance of fluids, electrolytes, acid-base homeostasis, and hormones [28]. AKI has gender dimorphic behavior. A meta-analysis by Grams et al. used the albumin-creatinine 
ratio (ACR) and estimated glomerular filtration rate (eGFR) as criteria to assess the renal function in AKI patients and found that the male sex is associated with an increased risk of AKI [29]. Another meta-analysis related to AKI that progressed in hospitalized patients (HAAKI) found that the prevalence of HAAKI changes according to the diagnostic criteria for AKI. Although the cohorts that used the Kidney Disease: Improving Global Outcomes (KDIGO) criteria determined that being of the male sex is a factor for developing HAAKI, results following the use of the RIFLE, an acronym of risk, injury, and failure; loss; and end-stage kidney disease, and the AKI Network (AKIN) criteria did not determine any significant differences between genders [30]. Interestingly, the KDIGO guidelines associate female sex with a higher risk of suffering AKI [31]. However, multiple studies have demonstrated a protective role of the female sex in different kidney diseases. O'Brien et al. indicate in a cohort report that being of the female sex improves survival in severe AKI, independent of sex hormone levels [32]. In the advanced stages of AKI, renal replacement therapies (RRT) are an alternative for a better quality of life.Males are at twice the risk of developing AKI that requires RRT than women [33]. In a drug-induced AKI injury model in rodents, males showed a higher predisposition to experiencing endoplasmic reticulum-stress and $\mathrm{Bcl}-2$ Associated X-protein and Caspase- 3 activation, which promotes apoptosis. Additionally, both sexes present differences in the location of tissue damage. Damage is markedly present in proximal tubules (PT) in the outer cortex, particularly in segments S1 and S2, in males and in the PT inner cortex, specifically in segment S3, in females. These factors could partly explain kidney damage susceptibility in males [34]. In a cisplatin-induced AKI model, females had less affectation of their tissue structure and had improved renal function [35]. Moreover, inflammatory responses are enhanced in male mice compared to female mice [36].

Epithelial cell injury as it relates to kidney disease also contributes to a constant state of chronic inflammation through the persistent release of chemotactic cytokines. Although most studies generally describe the inflammatory process without the distinction of sex, testosterone and estrogen influence many of the processes implicated in the synthesis and release of cytokines [37]. There are several potential explanations for this phenomenon. One explanation is that inflammation increases oxidative stress. In this regard, estrogens possess strong antioxidant activity, and as a result, they can significantly decrease injury [38]. On the other hand, it is known that inflammation causes damage at various levels of the endothelium [39]. Thus, abnormal endothelial function is noticed in postmenopausal women. However, with hormone replacement, endothelial function is re-established [40] Severe renal injury can be induced by ischemia-reperfusion (I-R). An I-R injury begins when oxygen levels decrease. The kidneys undergo an ischemic process with subsequent reperfusion. This process induces the release of different cytokines and growth factors that activate deleterious pathways [41] that affect the structure and physiology of the organ, leading to AKI [42].

\subsection{Chronic Kidney Disease}

Late stages of AKI could progress to chronic kidney disease (CKD). Lima I et al. described different factors between genders involved in the AKI transition to CKD in an I-R rat model. Four months after an I-R injury, the male animals presented with proteinuria, enhanced oxidative stress, tubular fibrosis, and glomerular hypertrophy. In contrast, females with AKI did not progress to CKD unless they were oophorectomized and as a result, had a similar pattern of damage to their male counterparts, suggesting the active participation of the sex hormones in the pathogenesis of kidney damage and CKD progression [43]. The differences between genders is remarkable. Evidence shows that women tend to suffer from CKD more frequently than men $[1,44]$, even though the rate of disease progression is higher in males [45-47]. Sex is also a determining factor for the progression to CKD. The most studied mechanism that is involved in this dimorphism is oxidative stress [48]. Evidence shows that the production of reactive oxygen species promotes kidney tissue injury, and this production is regulated by steroid hormones [49]. Testosterone directly 
inhibits antioxidant enzymes [50], and in contrast, estrogens attenuate superoxide production, protecting tissues from damage [51]. Furthermore, as time passes, higher levels of oxidative stress are observed in females compared to those observed in males [39]. A study with a cohort of 5488 subjects determined that the renal decline predictors in males were albuminuria, plasma glucose levels, and systolic blood pressure [52]. Moreover, in the alternative therapies for CKD treatment, men are at a higher risk for RRT $[53,54]$. Another study of 550 subjects receiving dialysis treatment used symptom questionnaires for reporting gender discrepancies in dialysis. The female sex is associated with higher symptomatology and delayed recovery from dialysis sessions when compared to the male sex. Males needed less time to recover post-dialysis [55]. In this type of RRT, the time, dose, and frequency of the sessions are essential to improve renal function. Women have an increased risk of mortality during dialysis treatment because they tend to have lower doses and dialysis sessions of less than $3 \mathrm{~h}[56,57]$.

\subsection{Renal Transplantation}

In many cases, when dialysis is no longer an effective therapy, it is recommended to make a progressive transition to alternative therapies such as kidney transplantation [58]. Nevertheless, sex differences were proposed as a risk factor for acute and chronic graft rejection. Meier et al. reported a 10\% higher risk of acute rejection in women compared to men in the 6 months following their kidney transplant. Interestingly, women had less risk of chronic allograft failure [59]. Gender should be a considered criteria in kidney transplants to reduce allograft rejection from decreased mismatch incompatibilities. A retrospective cohort found that a female-donor to a male-recipient had a risk of suffering graft rejection that was four times higher [60]. This result has been observed in many subsequent studies [61-63]. It is considered that kidney allograft survival is better in a maledonor to a male-recipient $[64,65]$. Many factors could be involved in these sex differences. In murine models, a protective role of female sex hormones on kidney allografts has been described $[65,66]$. Moreover, the H-Y alloantigen is associated with a sex mismatch in kidney transplantation [67-69]. Unfortunately, these results are still controversial. Another factor linked with allograft rejection is the organ size, as increased kidney donor mass is beneficial to the recipient. Miller et al. reported an increased risk of graft failure in a difference of $30 \mathrm{~kg}$ absolute weight between the recipient and donor, and this is often the case in transplants between a female-donor to a male-recipient. On the contrary, the kidney of a male-donor to a female-recipient had a higher glomerular number and less metabolic demand [62].

\subsection{Other Kidney-Related Diseases}

Diabetes and hypertension are some of the most common causes of kidney damage. The prevalence of diabetes kidney disease (DKD) between genders is still unclear. A metaanalysis reviewed articles about the association between diabetes and CKD or End-Stage Renal Disease (ESRD), and the analysis found that the female sex could increase progression to ESRD [70]. In a cohort study, diabetic men showed a higher prevalence of DKD than women; however, women presented a higher prevalence of the advanced stages of DKD than men [71]. The female predisposition to DKD progression might be explained by gender-associated frequency to DKD risk factors such as dyslipidemia [72,73], obesity [74], poor glucose control [72], and cardiovascular disease (CVD) [71]. Hypertension is a major risk factor for CVD. In women, there is a strong association between being overweight and developing hypertension [75]. The incidence is age-dependent and increases after menopause [76,77]. A study with hypertensive patients correlated the risk of developing CKD with hypertension in women [78]. A Chinese cohort described that higher systolic and diastolic blood pressure are associated with eGFR decline in men but not in women. An explanation for this result could be that the female group was not of menopausal age [79]. The age-dependent higher blood pressure in females has been explained by a decrease in 
ovarian hormones, particularly in estradiol, during menopause [80], improved angiotensin II, and reduced nitric oxide activity [81,82].

Other kidney diseases secondary to other pathologies or medications such as lupus nephritis (LN), focal segmental glomerulosclerosis (FSGS), and IgA nephropathy also show gender-specific behavior. In systemic lupus erythematous, men tend to progress faster to nephritis after lupus diagnosis than women [83]. In a global cohort of kidney disease, LN was a frequently glomerular affection in women [84]. However, a retrospective analysis found that more than $50 \%$ of men develop nephritis ten years after their lupus diagnosis. On the contrary, less than 30\% of women develop nephritis ten years after their lupus diagnosis [83]. Close to $30 \%$ of LN patients develop ESRD [85]. The male gender has been postulated as an independent risk factor for poor prognosis [86] and severe organ damage from this disease [87]. The protective role of the female sex in LN is conserved in FSGS. Cattran et al. reported a lower progression in renal deterioration and better outcomes when the disease was related to the proteinuria in women compared to men [88]. In this study, the authors found no sex differences in IgA nephropathy [88]. Nonetheless, other studies have mentioned faster eGFR decline, unfavorable clinicopathological characteristics, and rapid disease progression in men [47,89]. A meta-analysis by Neugarten et al. supports these findings, adding that men tend to have more adverse renal outcomes in idiopathic membranous nephropathy and autosomal dominant polycystic kidney disease than women [47].

Folic acid nephropathy is another model commonly used to generate renal interstitial fibrosis. Intraperitoneal high doses of folic acid in animals induce aggressive crystal formation with tubular necrosis [90]. In regard to this, most scientific articles report exclusively on males. Future studies are needed to validate the findings in female mice and make comparisons.

\section{Differences Associated with Factors Influencing Kidney Function}

Gender differences arise from genetics, race, age, and hormones that influence the predisposition, course, and resolution of kidney diseases. Some of these factors have been thoroughly studied for better understanding.

Studies suggest that specific single nucleotide polymorphisms (SNPs) are associated with gender susceptibility in the development of kidney disease. Gu et al. found an association between males and SNPs in insulin-like growth factor 2 MRNA binding protein 2 (IGF2BP2), rs1800471, and insulin-like growth factor 2 (IGF2), rs10770125, in diabetic nephropathy (DN) type 1 diabetes (T1D) patients. These SNPs protect diabetic men against the development of DN [91]. In nephropathies, fibrosis formation is an unavoidable, deleterious repair mechanism in which different types of growth factors participate. Transforming growth factor-beta (TGF- $\beta$ ) is an essential cytokine involved in fibrogenesis and, as such, has been the subject of multiple studies [92]. Genetic variants of TGF- $\beta$ have been associated with kidney damage. In a Chinese cohort of renal dysfunction patients, the presence of T869C polymorphism in TGF- $\beta 1$ in males was associated with elevated serum creatinine concentration and a decrease in GFR [93]. In CKD patients, the SNP rs1800471 in the TGF- $\beta 1$ gene has been associated with an increased probability of disease occurrence in women [94]. Another kidney-related SNP was found in the homeodomain-interacting protein kinase-2 (HIPK2) gene and was associated with an increased risk of stone formation in males. This result confirms the higher tendency of men to develop kidney stones [95].

Microarray analysis found that roughly 24 transcripts are differentially expressed between genders in human tubulointerstitial compartments after kidney injury [96]. In mice, 27 genes had sex-specific differences related to xenobiotic metabolism and solute regulation [97], demonstrating how gene expression changes in response to different environments. In kidney transplantation, the transporters involved in the homeostasis of solutes change when cross-sex transplants occur [98]. Other polymorphisms involved in the susceptibility of renal damage are related to race. Apolipoprotein L1 (APOL1) is a genetic variant associated with a higher risk of kidney disease among African Americans [99]. This 
ethnic group presents a higher probability of progressing to ESRD [100]. In a cohort of CKD patients, African American subjects with APOL1 risk variants had faster eGFR decline than Caucasian patients [101]. Moreover, a study among young potential living kidney donors demonstrated that African American men with APOL1 variants had a higher risk of developing CKD in the future than African American women or the European American population [102].

In addition to genetic variants, morphological and physiological changes between races are involved in organ damage susceptibility. African Americans tend to develop more kidney damage due to a multifactorial environment [103-107]. In an early CKD study, African American men had worse hypertension at baseline than African American women or Caucasians, which affected CKD progression [108]. Furthermore, in RRT, African Americans experienced a higher risk of graft loss [109,110], delayed graft function [110], and increased donor kidney damage over time [111,112]. Nevertheless, there is a survival advantage among African American dialysis patients [113]. The survival advantage of dialysis has been associated with older age, especially in males in contexts of higher levels of inflammation [114].

Age is also an important factor to consider. The average kidney mass reduces with age due to a decrease in glomerular and tubular cells $[115,116]$. A comparison of subjects under the age of thirty to subjects over the age of seventy reported a $48 \%$ decrease in nephron number and cortical volume. Although women showed a smaller number of non-sclerotic glomeruli, this had no significant relationship with age [117]. Moreover, various studies suggest that the male gender may contribute to the acceleration of renal function loss related to age [118]. However, there are discrepancies among studies. A prospective study by Feton et al. in living kidney donors found a faster decrease in GFR in females than in males after 35 years of age [12]. A meta-analysis found no association between GFR decline and gender before 50 years of age, but, as age increases, there is a faster renal function decline in women than men [119]. Some authors explain these sex-dependent effects as the result the of sex hormones and their protective role in females.

\section{Influence of Sex Hormones in the Kidney}

Multiple studies have focused on sex hormones and their effects to elucidate the divergent response between genders in several diseases [120-122]. Androgens and estrogens have shown dimorphic gender behavior in some organ functions [123,124]. However, their role in the establishment and progression of renal diseases deserves special attention [46,125].

Testosterone is involved in ammonia metabolism and excretion [126], water handling through increasing the expression of certain aquaporin subunits [127], and urinary calcium clearance [128]. Quant et al. found that androgens may be involved in the upregulation of the renin-angiotensin system in the proximal tubules [18]. In the kidney, some of these functions are affected by pathological events caused by an endocrine imbalance. In CKD, sexual dysfunction is common in men [129]. Lower testosterone levels have a deleterious role since they are associated with an increased risk of developing CKD [130] and mortality in male patients receiving dialysis [131]. Shoskes et al. reported a higher risk of graft loss in male kidney transplant recipients with lower testosterone levels [132]. This protective role of testosterone has also been reported in murine models. In I-R kidney injury, orchiectomized rats showed higher renal impairment, which could be reversed by testosterone supplementation [133]. A different study reported that lower doses of testosterone decrease medullary tubular necrosis and regulate cytokines and T cells involved in inflammatory processes [134]. Interestingly, the protective role of this hormone in kidney disease is controversial. Several studies have also reported increased male susceptibility to develop kidney dysfunction in the presence of testosterone $[36,135,136]$. Indeed, orchiectomy reduces oxidative stress [135] and activates apoptosis signals [137,138]. Park et al. explored the molecular mechanism associated with testosterone-improved damage and reported a decreased activation of nitric oxide synthase, Akt signaling, and ERK/JNK phosphorylation [136]. 
In contrast, estrogen has shown a protective role in different models of kidney damage [139-141]. A murine ovariectomy model described the renal redox system's reduction and detrimental changes to the nephrons [142]. Nonetheless, it has been reported that the presence of testosterone, more so than the absence of estrogen, correlates with glomerulosclerosis formation [143] and podocyte damage [144]. Associated with these results in DKD, supplementation with $17 \beta$-Estradiol decreased albuminuria, tubulointerstitial fibrosis, and sclerotic glomeruli [145]. These effects could be partly explained as a hormonal influence on the expression of TGF- $\beta$ and collagen proteins $[145,146]$, leading to the modification of extracellular matrix synthesis and degradation [147]. Moreover, after the I-R injury, treatment with $17 \beta$-Estradiol contributed to renal regeneration through enhanced endothelial cell survival, reduced expression of inflammatory cytokines, and apoptosis [141]. Kummer et al. reported that the activation of estrogen receptor alpha (ER $\alpha)$ reduced podocyte death, possibly due to a stabilization of mitochondrial membrane potential and activation of mitogen-activated protein kinase signaling pathways [148]. Other estrogen renoprotective mechanisms include a decrease in glomerular endothelial permeability [149], an improvement in nitric oxide production, and a decrease in endothelin-1 overproduction after I-R [150]. Additionally, the presence of $17 \beta$-estradiol activates the PI3K/Akt pathway and upregulates endothelial nitric oxide synthase expression in vitro and in vivo [151-153].

Despite the abundance of information regarding the positive role of estrogen in the kidneys, Lakzaei et al. reported increased I-R damage in tissues treated with this hormone compared to those treated with with losartan and angiotensin-(1-7) [154]. In a cisplatininduced nephrotoxicity animal model, the estrogen-treated groups showed no favorable changes in renal damage resorption. The authors suggest that the presence of high levels of estrogen induces more cisplatin-related nephrotoxicity [155]. The protective role of estradiol is conserved in the renal allograft [156]. On the other hand, testosterone influences chronic allograft rejection [156] and exacerbates the associated nephropathy [66]. Surprisingly, the positive effects of estrogen on renal damage associated with allograft rejection are reversed by progesterone [157]. However, there are different opinions regarding the role of progesterone in these deleterious processes. In lupus-associated glomerulonephritis, progesterone decreases renal injury [158]. In an I-R induced AKI model, progesterone exhibited antioxidant and renoprotective functions in a dose-dependent manner $[40,159]$.

Currently, more research is needed to establish the different roles of sex hormones in the establishment and progression of renal diseases. Most of the studies have been focused on estrogen and testosterone. However, there is a gap in the information in this regard. Hormones like prolactin (PRL) may have importance in this context. Thus, understanding their sex-dependent role in kidney physiology and disease represents an opportunity for novel research.

\section{Influence of Prolactin in Kidney Function and Disease}

PRL is a $23 \mathrm{kDa}$ hormone with a variety of target organs and multiple physiological functions. The most recognized functions are reproduction, lactation, and homeostasis of water and solutes [160]. The participation of PRL in water homeostasis was first described in Teleostei fishes when researchers observed that under the hormone stimuli, hypophysectomized fishes could adapt to freshwater [161]. This mechanism is associated with active participation in changes in sodium, chloride (in lesser proportion), and water permeability [162]. Since then, different studies have focused on PRL as an osmoregulatory molecule in organisms and tissues [163]. In the kidneys, the PRL gene is expressed in the Bowman capsule and proximal tubules cells [164]. According to these results, Mountojoy et al. described specific PRL binding in epithelial proximal tubule cells in the medulla and cortex [165]. Furthermore, after being filtrated in the glomeruli, the major PRL activity occurs on the thick ascending limb of the loops of Henle, the distal tubule, and the collecting ducts [166]. In an albino rat model, Emmanuel et al. reported that around twenty percent of renal arterial PRL load is catabolized in the kidneys, and its clearance is approximately 
two-thirds of the overall metabolic disposition [167]. The PRL activity reported along the nephrons correlated with its function. In murine models and humans, the administration of this hormone induces sodium, potassium, and water decline [168-170]. Marshall et al. reported that dehydration and nephrectomy caused increased serum PRL concentration, confirming its participation in salt and water metabolism [171]. Moreover, PRL activity is regulated by various effectors, especially dopamine systems [172,173]. A study with castrated rats showed changes in the regulation of the PRL receptor caused by testosterone and estradiol. Indeed, the absence of these two sex hormones significantly improved the renal PRL receptor binding [174]. However, a study demonstrated that the renal effect of PRL depends on the absence of vasopressin stimuli [175].

PRL-mediated mechanisms influence the activity of adenylate cyclase [166] and the enzyme Na-K-ATPase [172,176]. A rodent model demonstrated the influence of sex hormones on the thiazide-sensitive $\mathrm{Na}^{+}-\mathrm{Cl}^{-}$cotransporter (NCC) expressed in the distal convolute tubule. This transporter is involved in $\mathrm{NaCl}$ reabsorption. PRL and other female hormones showed increasing NCC expression/phosphorylation in female rats. The authors associated these salt retention effects with the multiple physiological states experienced by women, such pregnancy or lactation [177].

An endocrine imbalance is common in kidney disease and is strongly associated with elevated PRL concentration [178]. Cowden et al. reported hyperprolactinemia in $32 \%$ of renal disease patients [179]. Another cohort found sexual dimorphism in the higher levels of PRL in hemodialyzed people. Women are more affected than men, with a frequency of 70-90\% compared to a frequency of approximately 20-50\% [180]. Higher concentrations of PRL have been associated with a worse disease prognosis. Nephron atrophy was related to changes in PRL levels in response to the damage. In an acute renal failure model, the serum concentration of PRL was increased, but not PRL binding. This may indicate that the hormone changes that respond to a kidney injury [181]. Furthermore, hyperprolactinemia is attributed to increased PRL secretion and decreased clearance due to tissue injury $[182,183]$. A study that enrolled hemodialysis patients supports this. The PRL metabolic clearance rates were decreased by 33\% in these patients when compared to the controls. The author discussed the possibility of inefficient PRL suppression due to dopamine [183]. Other studies argue that increased hormone levels are due to a decrease in glomerular filtration and renal function [184,185]. Although the high levels of PRL do not decrease with hemodialysis $[180,185]$, kidney transplantation can reduce PRL levels $[185,186]$. Another variable to consider in renal hyperprolactinemia is the influence of different drugs. Immunosuppressive therapy with cyclosporine A and azathioprine does not affect PRL concentration [186]. Nonetheless, methyldopa can change hormone levels by acting on the dopamine system [187], and glucocorticoids can reduce PRL receptor binding in rat kidneys [188].

The endothelium is one of the targets of PRL. A cohort study by Carrero et al. reported that every $10 \mathrm{ng} / \mathrm{mL}$ of increased serum PRL concentration enhanced both the risk of suffering a cardiovascular event in non-dialyzed CKD patients and the mortality associated with cardiovascular dysfunction in hemodialysis patients [189]. Interestingly, this negative association of PRL does not correlate with positive effects of PRL on blood vessels. PRL induces angiogenesis by promoting migration and tubule formation [190-192] See Figure 1. Moreover, PRL influences vascular tone by inducing vasodilatation [193] and vascular permeability [194]. Nevertheless, evidence points to a mechanism of proteolytic cleavage on PRL due to various metalloproteinases, bone morphogenetic protein-1, and the enzyme cathepsin D, followed by the subsequent release of vasoinhibins that act on the endothelium [192,195]. 


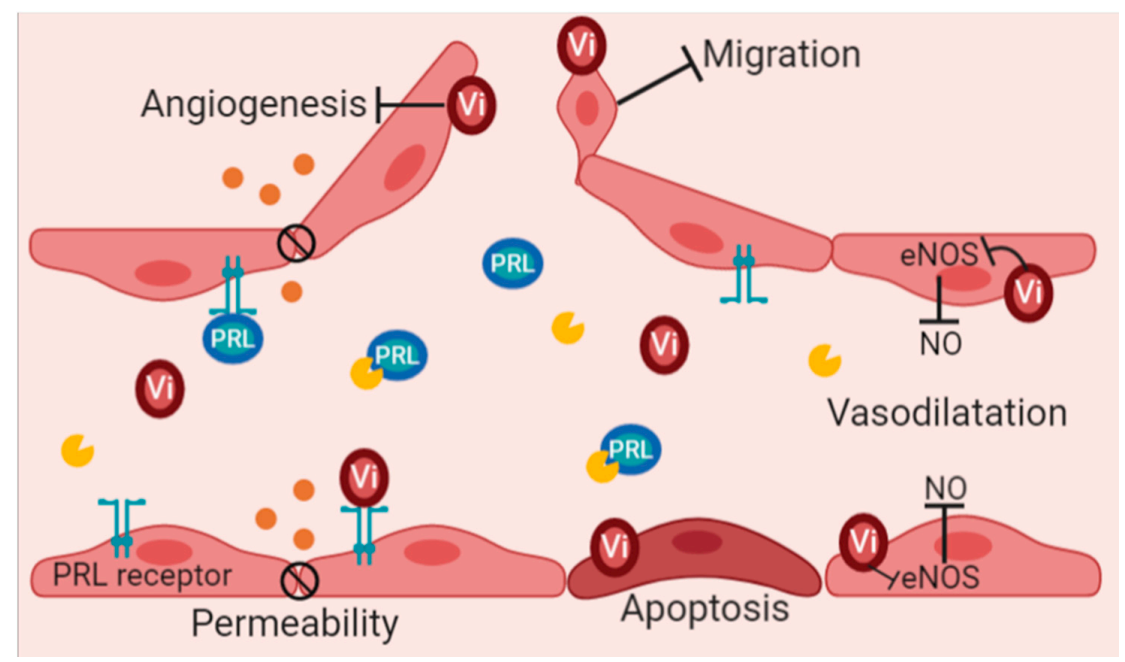

Figure 1. Influence of prolactin and Vasoinhibins on endothelial functions.

\section{Vasoinhibins and Their Potential Role in Renal Function}

Vasoinhibins are a family of fragments, cleavage products of various hormones of the PRL family, containing the N-terminal region of PRL, which confers their biological activity [195]. Although vasoinhibins of different sizes (11-18 kDa) have been reported, the most studied is the $16 \mathrm{kDa}$ variant [196]. The biological functions of vasoinhibins are recognized for being an antagonist to its hormone, PRL, precursor. Evidence postulates vasoinhibins as anti-angiogenic peptides with the ability to inhibit growth factors involved in vessel formation [197,198], to decrease migration [199], and to activate programmed cell death on endothelial cells [200], see Figure 1. Furthermore, vasoinhibins exert a vasomotor effect through the inhibition of enzymes involved directly in the production of nitric oxide, directly decreasing blood vessel dilation and permeability [201,202].

Though vasoinhibin peptides are primarily found in the mammary gland, the kidney is an organ with vasoinhibin presence [203]. Clapp et al. used pregnant rats to investigate specific binding sites for the $16 \mathrm{kDa}$ PRL variant in various organs. The result showed higher specificity and affinity binding sites in the kidney than in liver and the brain. Interestingly, the $16 \mathrm{kDa}$ PRL fragment demonstrated the ability to displace PRL from its receptor with higher potency in renal epithelial membranes. Hence, the authors discussed the possibility that vasoinhibins could regulate PRL target organs through their receptors [204]. Unfortunately, the role of these peptides in the kidneys is still mostly unknown. Despite this, vasoinhibins have been proposed as urinary biomarkers in preeclampsia by Leaños-Miranda et al., who reported higher urinary PRL levels in preeclampsia and found a PRL fragment associated with vasoinhibins in $21 \%$ of the patients with severe preeclampsia. The presence of vasoinhibins in this group of women was associated with worse outcomes, including the development of placenta abruption, pulmonary affections, and acute renal failure [205].

The kidney is a highly vascularized organ populated with a variety of endothelial cells. The endothelium plays an important role in the fulfillment of its functions. Endothelial damage causes renal injuries and results in posterior CKD [206]. The vascular actions of vasoinhibins in the renal endothelium might contribute to endothelial dysfunction in preeclamptic women, as described by Gonzalez, et al. They found that higher levels of vasoinhibins blocked vascular endothelial growth factor and its action on the endothelium [207]. Furthermore, cathepsin D (CTD) is an active producer of vasoinhibins [208,209] that has been associated with endothelial dysfunction in CKD patients [210]. In murine models, CTD improves fibrosis formation [211] and apoptosis [212], but alack of the enzyme increases the susceptibility kidney injury $[213,214]$. Interestingly, CTD is regulated by steroid hormones $[215,216]$. Estrogen induces CTD in the kidneys during renal tumorogenesis and is mediated by estrogen receptors [217]. Augereau et al. demonstrated the human 
CTD gene promoter has estrogen-responsive elements, explaining estrogen CTD-regulation via estrogen receptors [218] and might suggest a gender dimorphic behavior in CTD actions and consequently, increase vasoinhibins production. This gender difference was reported in ovariectomized estrogen-treated rats. Females had more endogenous vasoinhibins than males in the adenohypophyseal cells [208].

\section{Concluding Remarks}

Many factors involved in kidney physiology are influenced by gender. Several studies have shown female advantages that are especially associated with sexual hormones. This protection role seems to decrease in menopause and is related to the decline of estrogen levels. On the contrary, the influences of testosterone in men are associated with tissue damage in most of murine studies but not in humans. Various research demonstrates that the lack of the hormone increases is more significant in men with kidney disease. Furthermore, the evolution of kidney damage leads to endocrine dysfunction associated with the disruption of the eGFR. Hormones like PRL increase their concentration in CKD patients and are related to endothelial dysfunction and consequently, cardiovascular outcomes. Interestingly the angiogenic properties of this hormone do not correspond to its negative vascular associations. However, this must be analyzed with a focus on vasoinhibins. These fragments are probably effectors of renal endothelial dysfunction through the blockage of growth factors involved in blood formation and of decreased vascular dilatation and permeability.

It is crucial to mention potential gender differences in vasoinhibin formation. This might have a relation to the prevalence of hyperprolactinemia in CKD in women and CTD regulation by estrogen. Moreover, the enzyme CTD might contribute to endothelial damage, as was demonstrated by Ozkayar et al., in CKD patients. Unfortunately, the molecular mechanism associated with renal endothelial injury have not been studied enough. This might help in the development of strategies to decrease the damage associated with CTD. Currently, there are a few articles related to vasoinhibins and kidney pathophysiology. Future investigations are required to elucidate the participation of the prolactin/vasoinhibins axis in kidney disease with a specific focus on endothelial dysfunction and gender dimorphism. This information gap creates the opportunity for new research to elucidate the molecular mechanisms of the prolactin/vasoinhibins axis in kidney disease.

Author Contributions: Conceptualization, A.F.-A., Z.M. and R.E. literature review, A.F.-A., Z.M. and R.E. writing — original draft preparation, A.F.-A., R.E. and Z.M. writing—review and editing, R.E. and Z.M. All authors have read and agreed to the published version of the manuscript.

Funding: This review was funded by Consejo Nacional de Ciencia y Tecnología (CONACyT) México Grant "Ciencia de Frontera" 345366 FORDECYT-PRONACES awarded to Z.M.

Conflicts of Interest: The authors declare no conflict of interest.

\section{References}

1. Bikbov, B.; Perico, N.; Remuzzi, G.; on behalf of the GBD Genitourinary Diseases Expert Group. Disparities in Chronic Kidney Disease Prevalence among Males and Females in 195 Countries: Analysis of the Global Burden of Disease 2016 Study. Nephron 2018, 139, 313-318. [CrossRef] [PubMed]

2. Fraser, S.D.S.; Roderick, P.J. Kidney disease in the Global Burden of Disease Study. Nat. Rev. Nephrol. 2019, 15, 193-194. [CrossRef]

3. Palomino, J.; Echavarria, R.; Franco-Acevedo, A.; Moreno-Carranza, B.; Melo, Z. Opioids Preconditioning upon Renal Function and Ischemia-Reperfusion Injury: A Narrative Review. Medicina 2019, 55, 522. [CrossRef]

4. Sabolić, I.; Asif, A.R.; Budach, W.E.; Wanke, C.; Bahn, A.; Burckhardt, G. Gender differences in kidney function. Pflügers Arch. Eur. J. Physiol. 2007, 455, 397-429. [CrossRef] [PubMed]

5. Munger, K.; Baylis, C. Sex differences in renal hemodynamics in rats. Am. J. Physiol. Physiol. 1988, 254, F223-F231. [CrossRef] [PubMed]

6. Miletić, D.; Željko, F.; Šustić, A.; Mozetič, V.; Stimac, D.; Žauhar, G. Sonographic measurement of absolute and relative renal length in adults. J. Clin. Ultrasound 1998, 26, 185-189. [CrossRef]

7. Roseman, D.A.; Hwang, S.-J.; Oyama-Manabe, N.; Chuang, M.L.; O’Donnell, C.J.; Manning, W.J.; Fox, C.S. Clinical associations of total kidney volume: The Framingham Heart Study. Nephrol. Dial. Transplant. 2016, 32, 1344-1350. [CrossRef] 
8. Neugarten, J.; Kasiske, B.; Silbiger, S.R.; Nyengaard, J.R. Effects of sex on renal structure. Nephron 2002, 90, 139-144. [CrossRef]

9. Koenig, H.; Goldstone, A.; Blume, G.; Lu, C.Y. Testosterone-mediated sexual dimorphism of mitochondria and lysosomes in mouse kidney proximal tubules. Science 1980, 209, 1023-1026. [CrossRef]

10. Duann, P.; Lin, P.H. Mitochondria Damage and Kidney Disease. Adv. Exp. Med. Biol. 2017, 982, 529-551.

11. Hommos, M.; Glassock, R.J.; Rule, A.D. Structural and Functional Changes in Human Kidneys with Healthy Aging. J. Am. Soc. Nephrol. 2017, 28, 2838-2844. [CrossRef] [PubMed]

12. Fenton, A.; Montgomery, E.; Nightingale, P.; Peters, A.M.; Sheerin, N.; Wroe, A.C.; Lipkin, G.W. Glomerular filtration rate: New age- and gender- specific reference ranges and thresholds for living kidney donation. BMC Nephrol. 2018, 19, 336. [CrossRef]

13. James, G.D.; Sealey, D.J.E.; Alderman, M.; Ljungman, S.; Mueller, F.B.; Pecker, M.S.; Laragh, J.H. A Longitudinal Study of Urinary Creatinine and Creatinine Clearance in Normal Subjects: Race, Sex, and Age Differences. Am. J. Hypertens. 1988, 1, 124-131. [CrossRef] [PubMed]

14. Perucca, J.; Bouby, N.; Valeix, P.; Bankir, L. Sex difference in urine concentration across differing ages, sodium intake, and level of kidney disease. Am. J. Physiol. Integr. Comp. Physiol. 2007, 292, R700-R705. [CrossRef]

15. Godoy, D.A.; Alvarez, E.; Campi, V.; Soler, C.; Masotti, L.; Di Napoli, M. Diagnosis and therapy of polyuric states in patients with acute cerebral injury. Rev. Med. Chil. 2013, 141, 616-625. [CrossRef] [PubMed]

16. Veiras, L.C.; Girardi, A.C.C.; Curry, J.; Pei, L.; Ralph, D.L.; Tran, A.; Castelo-Branco, R.C.; Pastor-Soler, N.; Arranz, C.T.; Yu, A.S.L. Sexual Dimorphic Pattern of Renal Transporters and Electrolyte Homeostasis. J. Am. Soc. Nephrol. JASN 2017, $28,3504-3517$. [CrossRef]

17. Quigley, R. Androgens stimulate proximal tubule transport. Gend. Med. 2008, 5, S114-S120. [CrossRef] [PubMed]

18. Quan, A.; Chakravarty, S.; Chen, J.-K.; Loleh, S.; Saini, N.; Harris, R.C.; Capdevila, J.; Quigley, R. Androgens augment proximal tubule transport. Am. J. Physiol. Physiol. 2004, 287, F452-F459. [CrossRef]

19. Harris, A.N.; Lee, H.-W.; Osis, G.; Fang, L.; Webster, K.; Verlander, J.W.; Weiner, I.D. Differences in renal ammonia metabolism in male and female kidney. Am. J. Physiol. Physiol. 2018, 315, F211-F222. [CrossRef]

20. Anton, F.M.; Garcia Puig, J.; Ramos, T.; Gonzalez, P.; Ordas, J. Sex differences in uric acid metabolism in adults: Evidence for a lack of influence of estradiol-17 beta (E2) on the renal handling of urate. Metabolism 1986, 35, 343-348. [CrossRef]

21. Anzai, N.; Enomoto, A.; Endou, H. Renal urate handling: Clinical relevance of recent advances. Curr. Rheumatol. Rep. 2005, 7, 227-234. [CrossRef]

22. Perry, G.M.L.; Scheinman, S.J.; Asplin, J.R. Effects of Sex on Intra-Individual Variance in Urinary Solutes in Stone-Formers Collected from a Single Clinical Laboratory. PLoS ONE 2013, 8, e53637. [CrossRef]

23. Shoag, J.; Tasian, G.E.; Goldfarb, D.; Eisner, B.H. The New Epidemiology of Nephrolithiasis. Adv. Chronic Kidney Dis. 2015, 22, 273-278. [CrossRef] [PubMed]

24. Wang, S.; Zhang, Y.; Zhang, X.; Tang, Y.; Li, J. Upper urinary tract stone compositions: The role of age and gender. Int. Braz. J. Urol. 2020, 46, 70-80. [CrossRef] [PubMed]

25. Strope, S.A.; Wolf, J.S.; Hollenbeck, B.K. Changes in Gender Distribution of Urinary Stone Disease. Urology 2010, 75, 543-546.e1. [CrossRef] [PubMed]

26. Worcester, E.M.; Bergsland, K.J.; Gillen, D.L.; Coe, F.L. Mechanism for higher urine pH in normal women compared with men. Am. J. Physiol. Physiol. 2018, 314, F623-F629. [CrossRef]

27. Chen, H.-W.; Chen, Y.-C.; Yang, F.M.; Wu, W.-J.; Li, C.-C.; Chang, Y.-Y.; Chou, Y.-H. Mediators of the Effects of Gender on Uric Acid Nephrolithiasis: A Novel Application of Structural Equation Modeling. Sci. Rep. 2018, 8, 6077. [CrossRef]

28. Palevsky, P.M.; Liu, K.D.; Brophy, P.D.; Chawla, L.; Parikh, C.R.; Thakar, C.V.; Tolwani, A.J.; Waikar, S.S.; Weisbord, S.D. KDOQI US Commentary on the 2012 KDIGO Clinical Practice Guideline for Acute Kidney Injury. Am. J. Kidney Dis. 2013, 61, 649-672. [CrossRef]

29. Grams, M.E.; Sang, Y.; Ballew, S.H.; Gansevoort, R.T.; Kimm, H.; Kovesdy, C.P.; Naimark, D.; Oien, C.; Smith, D.H.; Coresh, J.; et al. A Meta-analysis of the Association of Estimated GFR, Albuminuria, Age, Race, and Sex with Acute Kidney Injury. Am. J. Kidney Dis. 2015, 66, 591-601. [CrossRef] [PubMed]

30. Neugarten, J.; Golestaneh, L. Female sex reduces the risk of hospital-associated acute kidney injury: A meta-analysis. BMC Nephrol. 2018, 19, 314. [CrossRef]

31. Schulte-Steinberg, H.; Weninger, E.; Jokisch, D.; Hofstetter, B.; Misera, A.; Lange, V.; Stein, C. Intraperitoneal Versus Interpleural Morphine or Bupivacaine for Pain after Laparoscopic Cholecystectomy. Anesthesiology 1995, 82, 634-640. [CrossRef] [PubMed]

32. O'Brien, Z.; Cass, A.; Cole, L.; Finfer, S.; Gallagher, M.; McArthur, C.; McGuiness, S.; Myburgh, J.; Bellomo, R.; Mårtensson, J. Sex and mortality in septic severe acute kidney injury. J. Crit. Care 2019, 49, 70-76. [CrossRef]

33. Neugarten, J.; Golestaneh, L.; Kolhe, N.V. Sex differences in acute kidney injury requiring dialysis. BMC Nephrol. 2018, $19,131$. [CrossRef]

34. Hodeify, R.; Megyesi, J.; Tarcsafalvi, A.; Mustafa, H.I.; Seng, N.S.H.L.; Price, P.M. Gender differences control the susceptibility to ER stress-induced acute kidney injury. Am. J. Physiol. Physiol. 2013, 304, F875-F882. [CrossRef]

35. Boddu, R.; Fan, C.; Rangarajan, S.; Sunil, R.; Bolisetty, S.; Curtis, L.M. Unique sex- and age-dependent effects in protective pathways in acute kidney injury. Am. J. Physiol. Physiol. 2017, 313, F740-F755. [CrossRef]

36. Kang, K.P.; Lee, J.E.; Lee, A.S.; Jung, Y.J.; Kim, D.; Lee, S.; Hwang, H.P.; Kim, W.; Park, S.K. Effect of gender differences on the regulation of renal ische-mia-reperfusion-induced inflammation in mice. Mol. Med. Rep. 2014, 9, 2061-2068. [CrossRef] [PubMed] 
37. Carrero, J.J. Gender Differences in Chronic Kidney Disease: Underpinnings and Therapeutic Implications. Kidney Blood Press. Res. 2010, 33, 383-392. [CrossRef] [PubMed]

38. Ma, H.-Y.; Chen, S.; Du, Y. Estrogen and estrogen receptors in kidney diseases. Ren. Fail. 2021, 43, 619-642. [CrossRef]

39. Lima-Posada, I.; Bobadilla, N.A. Understanding the opposite effects of sex hormones in mediating renal injury. Nephrology 2021, 26, 217-226. [CrossRef]

40. Stenvinkel, P.; Wanner, C.; Metzger, T.; Heimbürger, O.; Mallamaci, F.; Tripepi, G.; Malatino, L.; Zoccali, C. Inflammation and outcome in end-stage renal failure: Does female gender constitute a survival advantage? Kidney Int. 2002, 62, 1791-1798. [CrossRef]

41. Eltzschig, H.K.; Eckle, T. Ischemia and reperfusion-From mechanism to translation. Nat. Med. 2011, 17, 1391-1401. [CrossRef]

42. Sharfuddin, A.A.; Molitoris, B.A. Pathophysiology of ischemic acute kidney injury. Nat. Rev. Nephrol. 2011, 7, 189-200. [CrossRef]

43. Lima-Posada, I.; Portas-Cortés, C.; Pérez-Villalva, R.; Fontana, F.; Rodríguez-Romo, R.; Prieto, R.; Sánchez-Navarro, A.; RodríguezGonzález, G.L.; Gamba, G.; Zambrano, E.; et al. Gender Differences in the Acute Kidney Injury to Chronic Kidney Disease Transition. Sci. Rep. 2017, 7, 1-13. [CrossRef]

44. Hill, N.R.; Fatoba, S.T.; Oke, J.L.; Hirst, J.; O'Callaghan, C.A.; Lasserson, D.; Hobbs, R. Global Prevalence of Chronic Kidney Disease-A Systematic Review and Meta-Analysis. PLoS ONE 2016, 11, e0158765. [CrossRef] [PubMed]

45. Brar, A.; Markell, M. Impact of gender and gender disparities in patients with kidney disease. Curr. Opin. Nephrol. Hypertens. 2019, 28, 178-182. [CrossRef] [PubMed]

46. Valdivielso, J.M.; Jacobs-Cachá, C.; Soler, M.J. Sex hormones and their influence on chronic kidney disease. Curr. Opin. Nephrol. Hypertens. 2019, 28, 1-9. [CrossRef] [PubMed]

47. Neugarten, J.; Acharya, A.; Silbiger, S.R. Effect of gender on the progression of nondiabetic renal disease: A meta-analysis. J. Am. Soc. Nephrol. JASN 2000, 11, 319-329. [CrossRef]

48. Pan, J.S.; Sheikh-Hamad, D. Mitochondrial dysfunction in acute kidney injury and sex-specific implications. Med. Res. Arch. 2019, 7. [CrossRef]

49. Cobo, G.; Hecking, M.; Port, F.K.; Exner, I.; Lindholm, B.; Stenvinkel, P.; Carrero, J.J. Sex and gender differences in chronic kidney disease: Progression to end-stage renal disease and haemodialysis. Clin. Sci. 2016, 130, 1147-1163. [CrossRef]

50. Zhang, G.; Kang, Y.; Zhou, C.; Cui, R.; Jia, M.; Hu, S.; Ji, X.; Yuan, J.; Cui, X.; Shi, G. Amelioratory Effects of Testosterone Propionate on Age-related Renal Fibrosis via Suppression of TGF-beta1/Smad Signaling and Activation of Nrf2-ARE Signaling. Sci Rep. 2018, 8, 10726. [CrossRef]

51. Park, Y.J.; Kim, J.-M. Klotho and Postmenopausal Hormone Replacement Therapy in Women with Chronic Kidney Disease. J. Menopausal Med. 2018, 24, 75-80. [CrossRef] [PubMed]

52. Halbesma, N.; Brantsma, A.H.; Bakker, S.J.; Jansen, D.F.; Stolk, R.P.; De Zeeuw, D.; Jong, P.E.D.; Gansevoort, R.T.; PREVEND Study Group. Gender differences in predictors of the decline of renal function in the general population. Kidney Int. 2008, 74, 505-512. [CrossRef]

53. Antlanger, M.; Noordzij, M.; Van De Luijtgaarden, M.; Carrero, J.J.; Palsson, R.; Finne, P.; Hemmelder, M.H.; Aresté-Fosalba, N.; Reisæter, A.V.; Cases, A.; et al. Sex Differences in Kidney Replacement Therapy Initiation and Maintenance. Clin. J. Am. Soc. Nephrol. 2019, 14, 1616-1625. [CrossRef] [PubMed]

54. Piras, D.; Masala, M.; Delitala, A.; Urru, S.A.M.; Curreli, N.; Balaci, L.; Ferreli, L.P.; Loi, F.; Atzeni, A.; Cabiddu, G.; et al. Kidney size in relation to ageing, gender, renal function, birthweight and chronic kidney disease risk factors in a general population. Nephrol. Dial. Transplant. 2020, 35, 640-647. [CrossRef] [PubMed]

55. Caplin, B.; Kumar, S.; Davenport, A. Patients' perspective of haemodialysis-associated symptoms. Nephrol. Dial. Transplant. 2011, 26, 2656-2663. [CrossRef] [PubMed]

56. Miller, J.E.; Kovesdy, C.P.; Nissenson, A.R.; Mehrotra, R.; Streja, E.; Van Wyck, D.; Greenland, S.; Kalantar-Zadeh, K. Association of Hemodialysis Treatment Time and Dose with Mortality and the Role of Race and Sex. Am. J. Kidney Dis. 2010, 55, 100-112. [CrossRef]

57. Couchoud, C.; Kooman, J.; Finne, P.; Leivestad, T.; Stojceva-Taneva, O.; Ponikvar, J.B.; Collart, F.; Kramar, R.; de Fransicso, A.; Jager, K.J.; et al. From registry data collection to inter-national comparisons: Examples of haemodialysis duration and frequency. Nephrol. Dial. Transplant. 2009, 24, 217-224. [CrossRef] [PubMed]

58. Kalantar-Zadeh, K.; Kovesdy, C.P.; Streja, E.; Rhee, C.M.; Soohoo, M.; Chen, J.L.; Molnar, M.Z.; Obi, Y.; Gillen, D.; Nguyen, D.V.; et al. Transition of care from pre-dialysis prelude to renal replacement therapy: The blueprints of emerging research in advanced chronic kidney disease. Nephrol. Dial. Transplant. 2017, 32, ii91-ii98. [CrossRef] [PubMed]

59. Meier-Kriesche, H.-U.; Ojo, A.O.; Leavey, S.F.; Hanson, J.A.; Leichtman, A.B.; Magee, J.C.; Cibrik, D.M.; Kaplan, B. Gender Differences in the Risk for Chronic Renal Allograft Failure. Transplantation 2001, 71, 429-432. [CrossRef]

60. Baddiri, A.T.; Villanueva, R.T.; Cabanayan-Casasola, C.B. Impact of Age Difference, Sex Matching, and Body Mass Index Matching Between Donor and Recipient in Renal Transplant. Transplant. Proc. 2019, 51, 2568-2574. [CrossRef]

61. Matter, Y.E.; Elhadedy, M.A.; Abbas, T.M.; Zahab, M.A.; Fouda, M.A.; Refaie, A.F.; Sheashaa, H.A.; Abbas, M.H.; Denewar, A.A.; Nagib, A.M. Impact of Sex Disparities on Outcomes of Liv-ing-Donor Kidney Transplant in Egypt: Data of 979 Patients. Exp. Clin. Transplant. 2018, 16, 133-137. [PubMed]

62. Miller, A.J.; Kiberd, B.A.; Alwayn, I.P.; Odutayo, A.; Tennankore, K.K. Donor-Recipient Weight and Sex Mismatch and the Risk of Graft Loss in Renal Transplantation. Clin. J. Am. Soc. Nephrol. 2017, 12, 669-676. [CrossRef] [PubMed] 
63. Yoneda, T.; Iemura, Y.; Onishi, K.; Hori, S.; Nakai, Y.; Miyake, M.; Anai, S.; Torimoto, K.; Aoki, K.; Saka, T.; et al. Effect of Gender Differences on Transplant Kidney Function. Transplant. Proc. 2017, 49, 61-64. [CrossRef] [PubMed]

64. Santiago, E.V.; Silveira, M.R.; Araujo, V.E.; Farah Kde, P.; Acurcio Fde, A.; Ceccato, M. Gender in the allocation of organs in kidney transplants: Meta-analysis. Rev. Saude Publica 2015, 49, 68. [CrossRef]

65. Zhou, J.-Y.; Cheng, J.; Huang, H.-F.; Shen, Y.; Jiang, Y.; Chen, J.-H. The effect of donor-recipient gender mismatch on short- and long-term graft survival in kidney transplantation: A systematic review and meta-analysis. Clin. Transplant. 2013, 27, 764-771. [CrossRef]

66. Antus, B.; Yao, Y.; Song, E.; Liu, S.; Lutz, J.; Heemann, U. Opposite effects of testosterone and estrogens on chronic allograft nephropathy. Transpl. Int. 2002, 15, 494-501. [CrossRef] [PubMed]

67. Gratwohl, A.; Döhler, B.; Stern, M.; Opelz, G. H-Y as a minor histocompatibility antigen in kidney transplantation: A retrospective cohort study. Lancet 2008, 372, 49-53. [CrossRef]

68. Kim, S.J.; Gill, J.S. H-Y Incompatibility Predicts Short-Term Outcomes for Kidney Transplant Recipients. J. Am. Soc. Nephrol. 2009, 20, 2025-2033. [CrossRef]

69. Tan, J.C.; Kim, J.P.; Chertow, G.M.; Grumet, F.C.; Desai, M. Donor-recipient sex mismatch in kidney transplantation. Gend. Med. 2012, 9, 335-347.e2. [CrossRef]

70. Shen, Y.; Cai, R.; Sun, J.; Dong, X.; Huang, R.; Tian, S.; Wang, S. Diabetes mellitus as a risk factor for incident chronic kidney disease and end-stage renal disease in women compared with men: A systematic review and meta-analysis. Endocrine 2017, 55, 66-76. [CrossRef]

71. Yu, M.K.; Lyles, C.R.; Bent-Shaw, L.A.; Young, B.A.; the Pathways Authors. Risk Factor, Age and Sex Differences in Chronic Kidney Disease Prevalence in a Diabetic Cohort: The Pathways Study. Am. J. Nephrol. 2012, 36, 245-251. [CrossRef]

72. Nilsson, P.M.; Theobald, H.; Journath, G.; Fritz, T. Gender differences in risk factor control and treatment profile in diabetes: A study in 229 swedish primary health care centres. Scand. J. Prim. Heal. Care 2004, 22, 27-31. [CrossRef] [PubMed]

73. Gouni-Berthold, I.; Berthold, H.K.; Mantzoros, C.S.; Bohm, M.; Krone, W. Sex disparities in the treatment and control of cardio-vascular risk factors in type 2 diabetes. Diabetes Care 2008, 31, 1389-1391. [CrossRef] [PubMed]

74. Wells, J.C.; Marphatia, A.A.; Cole, T.; McCoy, D. Associations of economic and gender inequality with global obesity prevalence: Understanding the female excess. Soc. Sci. Med. 2012, 75, 482-490. [CrossRef] [PubMed]

75. Wakabayashi, I. Stronger associations of obesity with prehypertension and hypertension in young women than in young men. J. Hypertens. 2012, 30, 1423-1429. [CrossRef]

76. Di Giosia, P.; Giorgini, P.; Stamerra, C.A.; Petrarca, M.; Ferri, C.; Sahebkar, A. Gender Differences in Epidemiology, Pathophysiology, and Treatment of Hypertension. Curr. Atheroscler. Rep. 2018, 20, 13. [CrossRef] [PubMed]

77. Reckelhoff, J.F. Gender differences in hypertension. Curr. Opin. Nephrol. Hypertens. 2018, 27, 176-181. [CrossRef]

78. Tziomalos, K.; Giampatzis, V.; Baltatzi, M.; Efthymiou, E.; Psianou, K.; Papastergiou, N.; Magkou, D.; Bougatsa, V.; Savopoulos, C.; Hatzitolios, A.I. Sex-specific differences in cardio-vascular risk factors and blood pressure control in hypertensive patients. J. Clin. Hypertens 2014, 16, 309-312. [CrossRef] [PubMed]

79. Wang, Q.; Xie, D.; Xu, X.; Qin, X.; Tang, G.; Wang, B.; Wang, Y.; Hou, F.; Xu, X.; Wang, X. Blood pressure and renal function decline: A 7-year prospective cohort study in middle-aged rural Chinese men and women. J. Hypertens. 2015, 33, 136-143. [CrossRef]

80. Dubey, R.K.; Oparil, S.; Imthurn, B.; Jackson, E.K. Sex hormones and hypertension. Cardiovasc. Res. 2002, 53, 688-708. [CrossRef]

81. Sullivan, J.C. Sex and the renin-angiotensin system: Inequality between the sexes in response to RAS stimulation and inhibition. Am. J. Physiol. Integr. Comp. Physiol. 2008, 294, R1220-R1226. [CrossRef]

82. Hernandez Schulman, I.; Raij, L. Salt sensitivity and hypertension after menopause: Role of nitric oxide and angiotensin II. Am. J. Nephrol. 2006, 26, 170-180. [CrossRef]

83. Seligman, V.A.; Lum, R.F.; Olson, J.L.; Li, H.; Criswell, L.A. Demographic differences in the development of lupus nephritis: A retrospective analysis. Am. J. Med. 2002, 112, 726-729. [CrossRef]

84. O'Shaughnessy, M.; Hogan, S.L.; Thompson, B.D.; Coppo, R.; Fogo, A.B.; Jennette, J.C. Glomerular disease frequencies by race, sex and region: Results from the International Kidney Biopsy Survey. Nephrol. Dial. Transplant. 2018, 33, 661-669. [CrossRef] [PubMed]

85. Maroz, N.; Segal, M.S. Lupus nephritis and end-stage kidney disease. Am. J. Med. Sci. 2013, 346, 319-323. [CrossRef] [PubMed]

86. Hsu, C.-Y.; Chiu, W.-C.; Yang, T.-S.; Chen, C.-J.; Chen, Y.-C.; Lai, H.-M.; Yu, S.-F.; Su, Y.-J.; Cheng, T.-T. Age- and gender-related long-term renal outcome in patients with lupus nephritis. Lupus 2011, 20, 1135-1141. [CrossRef]

87. Peng, W.; Tang, Y.; Tan, L.; Qin, W. Clinicopathological study of male and female patients with lupus nephritis: A retrospective study. Int. Urol. Nephrol. 2018, 50, 313-320. [CrossRef] [PubMed]

88. Cattran, D.C.; Reich, H.N.; Beanlands, H.J.; Miller, J.A.; Scholey, J.W.; Troyanov, S. The impact of sex in primary glomerulonephritis. Nephrol. Dial. Transplant. 2008, 23, 2247-2253. [CrossRef]

89. Deng, W.; Tan, X.; Zhou, Q.; Ai, Z.; Liu, W.; Chen, W.; Yu, X.; Yang, Q. Gender-related differences in clinicopathological characteristics and renal outcomes of Chinese patients with IgA nephropathy. BMC Nephrol. 2018, 19, 1-8. [CrossRef]

90. Yang, H.-C.; Zuo, Y.; Fogo, A.B. Models of chronic kidney disease. Drug Discov. Today Dis. Model. 2010, 7, 13-19. [CrossRef]

91. Gu, T.; Horová, E.; Möllsten, A.; Seman, N.A.; Falhammar, H.; Prázný, M.; Brismar, K.; Gu, H.F. IGF2BP2 and IGF2 genetic effects in diabetes and diabetic nephropathy. J. Diabetes Complicat. 2012, 26, 393-398. [CrossRef] [PubMed] 
92. Hu, H.H.; Chen, D.Q.; Wang, Y.N.; Feng, Y.L.; Cao, G.; Vaziri, N.D.; Zhao, Y.-Y. New insights into TGF-beta/Smad signaling in tissue fibrosis. Chem. Biol. Interact. 2018, 292, 76-83. [CrossRef]

93. Hu, B.C.; Chu, S.L.; Wang, G.L.; Gao, P.J.; Zhu, D.L.; Wang, J.G. Association between genetic variation in transforming growth factors beta1 and beta3 and renal dysfunction in non-diabetic Chinese. Clin. Exp. Hypertens. 2008, 30, 121-131. [CrossRef]

94. Nabrdalik, K.; Gumprecht, J.; Adamczyk, P.; Gorczynska-Kosiorz, S.; Zywiec, J.; Grzeszczak, W. Association of rs1800471 poly-morphism of TGFB1 gene with chronic kidney disease occurrence and progression and hypertension appearance. Arch. Med. Sci. 2013, 9, 230-237. [CrossRef]

95. Lin, H.; Zhu, X.; Long, J.; Chen, Y.; Xie, Y.; Liao, M.; Chen, J.; Tian, J.; Huang, S.; Tang, R.; et al. HIPK2 polymorphisms rs2058265, rs6464214, and rs7456421 were associated with kidney stone disease in Chinese males not females. Gene 2018, 653, 51-56. [CrossRef] [PubMed]

96. Si, H.; Banga, R.S.; Kapitsinou, P.; Ramaiah, M.; Lawrence, J.; Kambhampati, G.; Gruenwald, A.; Böttinger, E.; Glicklich, D.; Tellis, V.; et al. Human and Murine Kidneys Show Gender- and Species-Specific Gene Expression Differences in Response to Injury. PLoS ONE 2009, 4, e4802. [CrossRef] [PubMed]

97. Rinn, J.L.; Rozowsky, J.S.; Laurenzi, I.J.; Petersen, P.H.; Zou, K.; Zhong, W.; Gerstein, M.; Snyder, M. Major Molecular Differences between Mammalian Sexes Are Involved in Drug Metabolism and Renal Function. Dev. Cell 2004, 6, 791-800. [CrossRef]

98. Wang, L.; Song, J.; Wang, S.; Buggs, J.; Chen, R.; Zhang, J.; Wang, L.; Rong, S.; Li, W.; Wei, J.; et al. Cross-sex transplantation alters gene expression and enhances inflammatory response in the transplanted kidneys. Am. J. Physiol. Physiol. 2017, 313, F326-F338. [CrossRef] [PubMed]

99. Genovese, G.; Friedman, D.J.; Ross, M.D.; Lecordier, L.; Uzureau, P.; Freedman, B.I.; Bowden, D.W.; Langefeld, C.D.; Oleksyk, T.K.; Knob, A.L.U.; et al. Association of Trypanolytic ApoL1 Variants with Kidney Disease in African Americans. Science 2010, 329, 841-845. [CrossRef]

100. Fedewa, S.A.; McClellan, W.M.; Judd, S.; Gutiérrez, O.M.; Crews, D.C. The association between race and income on risk of mortality in patients with moderate chronic kidney disease. BMC Nephrol. 2014, 15, 136. [CrossRef]

101. Parsa, A.; Kao, W.L.; Xie, D.; Astor, B.C.; Li, M.; Hsu, C.-Y.; Feldman, H.I.; Parekh, R.S.; Kusek, J.W.; Greene, T.; et al. APOL1 Risk Variants, Race, and Progression of Chronic Kidney Disease. N. Engl. J. Med. 2013, 369, 2183-2196. [CrossRef] [PubMed]

102. Locke, J.E.; Sawinski, D.; Reed, R.D.; Shelton, B.; MacLennan, P.A.; Kumar, V.; Mehta, S.; Mannon, R.B.; Gaston, R.; Julian, B.A.; et al. Apolipoprotein L1 and Chronic Kidney Disease Risk in Young Potential Living Kidney Donors. Ann. Surg. 2018, 267, 1161-1168. [CrossRef]

103. Barbour, S.J.; Schachter, M.; Er, L.; Djurdjev, O.; Levin, A. A systematic review of ethnic differences in the rate of renal pro-gression in CKD patients. Nephrol. Dial. Transplant. 2010, 25, 2422-2430. [CrossRef]

104. Laster, M.; Shen, J.I.; Norris, K.C. Kidney Disease Among African Americans: A Population Perspective. Am. J. Kidney Dis. 2018, 72, S3-S7. [CrossRef]

105. Bryson, C.L.; Ross, H.J.; Boyko, E.J.; Young, B.A. Racial and ethnic variations in albuminuria in the US Third National Health and Nutrition Examination Survey (NHANES III) population: Associations with diabetes and level of CKD. Am. J. Kidney Dis. 2006, 48, 720-726. [CrossRef] [PubMed]

106. Hughson, M.D.; Puelles, V.; Hoy, W.E.; Douglas-Denton, R.N.; Mott, S.A.; Bertram, J. Hypertension, glomerular hypertrophy and nephrosclerosis: The effect of race. Nephrol. Dial. Transplant. 2014, 29, 1399-1409. [CrossRef]

107. Abdi, R.; Slakey, D.; Kittur, D.; Racusen, L.C. Heterogeneity of glomerular size in normal donor kidneys: Impact of race. Am. J. Kidney Dis. 1998, 32, 43-46. [CrossRef]

108. Duru, O.K.; Li, S.; Jurkovitz, C.; Bakris, G.; Brown, W.; Chen, S.-C.; Collins, A.; Klag, M.; McCullough, P.A.; McGill, J.; et al. Race and Sex Differences in Hypertension Control in CKD: Results from the Kidney Early Evaluation Program (KEEP). Am. J. Kidney Dis. 2008, 51, 192-198. [CrossRef] [PubMed]

109. Narayanan, M.; Pankewycz, O.; El-Ghoroury, M.; Shihab, F.; Wiland, A.; McCague, K.; Chan, L. Outcomes in African American Kidney Transplant Patients Receiving Tacrolimus and Mycophenolic Acid Immunosuppression. Transplantation 2013, 95, 566-572. [CrossRef]

110. Eckhoff, D.E.; Young, C.J.; Gaston, R.S.; Fineman, S.W.; Deierhoi, M.H.; Foushee, M.T.; Brown, R.N.; Diethelm, A.G. Racial Disparities in Renal Allograft Survival: A Public Health Issue? J. Am. Coll. Surg. 2007, 204, 894-902. [CrossRef]

111. Gibney, E.; Parikh, C.; Garg, A. Age, Gender, Race, and Associations With Kidney Failure Following Living Kidney Donation. Transplant. Proc. 2008, 40, 1337-1340. [CrossRef] [PubMed]

112. Lentine, K.L.; Schnitzler, M.A.; Garg, A.X.; Xiao, H.; Axelrod, D.; Tuttle-Newhall, J.E.; Brennan, D.C.; Segev, D.L. Race, Relationship and Renal Diagnoses After Living Kidney Donation. Transplantation 2015, 99, 1723-1729. [CrossRef] [PubMed]

113. Kucirka, L.M.; Grams, M.E.; Lessler, J.; Hall, E.C.; James, N.T.; Massie, A.B.; Montgomery, R.A.; Segev, D.L. Association of Race and Age with Survival Among Patients Undergoing Dialysis. JAMA 2011, 306, 620-626. [CrossRef]

114. Crews, D.C.; Sozio, S.; Liu, Y.; Coresh, J.; Powe, N.R. Inflammation and the Paradox of Racial Differences in Dialysis Survival. J. Am. Soc. Nephrol. 2011, 22, 2279-2286. [CrossRef]

115. Goyal, V. Changes with age in the human kidney. Exp. Gerontol. 1982, 17, 321-331. [CrossRef]

116. Nyengaard, J.R.; Bendtsen, T.F. Glomerular number and size in relation to age, kidney weight, and body surface in normal man. Anat. Rec. 1992, 232, 194-201. [CrossRef] 
117. Denic, A.; Lieske, J.C.; Chakkera, H.A.; Poggio, E.D.; Alexander, M.P.; Singh, P.; Kremers, W.K.; Lerman, L.O.; Rule, A.D. The Substantial Loss of Nephrons in Healthy Human Kidneys with Aging. J. Am. Soc. Nephrol. 2016, 28, 313-320. [CrossRef]

118. Weinstein, J.R.; Anderson, S. The aging kidney: Physiological changes. Adv. Chronic Kidney Dis. 2010, 17, 302-307. [CrossRef] [PubMed]

119. Pottel, H.; Hoste, L.; Yayo, E.; Delanaye, P. Glomerular Filtration Rate in Healthy Living Potential Kidney Donors: A Meta-Analysis Supporting the Construction of the Full Age Spectrum Equation. Nephron 2017, 135, 105-119. [CrossRef] [PubMed]

120. Boese, A.C.; Kim, S.C.; Yin, K.-J.; Lee, J.-P.; Hamblin, M.H. Sex differences in vascular physiology and pathophysiology: Estrogen and androgen signaling in health and disease. Am. J. Physiol. Circ. Physiol. 2017, 313, H524-H545. [CrossRef]

121. Ngo, S.; Steyn, F.; McCombe, P. Gender differences in autoimmune disease. Front. Neuroendocr. 2014, 35, 347-369. [CrossRef] [PubMed]

122. Ding, E.L.; Song, Y.; Malik, V.S.; Liu, S. Sex differences of endogenous sex hormones and risk of type 2 diabetes: A systematic review and meta-analysis. JAMA 2006, 295, 1288-1299. [CrossRef]

123. Dos Santos, R.L.; da Silva, F.B.; Ribeiro, R.F., Jr.; Stefanon, I. Sex hormones in the cardiovascular system. Horm. Mol. Biol. Clin. Investig. 2014, 18, 89-103. [CrossRef] [PubMed]

124. Sathish, V.; Martin, Y.N.; Prakash, Y. Sex steroid signaling: Implications for lung diseases. Pharmacol. Ther. 2015, 150, 94-108. [CrossRef] [PubMed]

125. Grossmann, M.; Hoermann, R.; Fui, M.N.T.; Zajac, J.D.; Ierino, F.L.; Roberts, M.A. Sex steroids levels in chronic kidney disease and kidney transplant recipients: Associations with disease severity and prediction of mortality. Clin. Endocrinol. 2014, 82, 767-775. [CrossRef]

126. Harris, A.N.; Lee, H.-W.; Verlander, J.W.; Weiner, I.D. Testosterone modulates renal ammonia metabolism. Am. J. Physiol. Physiol. 2020, 318, F922-F935. [CrossRef] [PubMed]

127. Loh, S.Y.; Giribabu, N.; Salleh, N. Effects of gonadectomy and testosterone treatment on aquaporin expression in the kidney of normotensive and hypertensive rats. Exp. Biol. Med. 2017, 242, 1376-1386. [CrossRef] [PubMed]

128. Hsu, Y.-J.; Dimke, H.; Schoeber, J.P.; Hsu, S.-C.; Lin, S.-H.; Chu, P.; Hoenderop, J.G.; Bindels, R.J. Testosterone increases urinary calcium excretion and inhibits expression of renal calcium transport proteins. Kidney Int. 2010, 77, 601-608. [CrossRef]

129. Carrero, J.J.; Qureshi, A.R.; Nakashima, A.; Arver, S.; Parini, P.; Lindholm, B.; Bárány, P.; Heimbürger, O.; Stenvinkel, P. Prevalence and clinical implications of tes-tosterone deficiency in men with end-stage renal disease. Nephrol. Dial. Transplant. 2011, 26, 184-190. [CrossRef] [PubMed]

130. Amiri, M.; Tehrani, F.R.; Rahmati, M.; Soudmand, S.A.; Behboudi-Gandevani, S.; Sabet, Z.; Azizi, F. Low serum testosterone levels and the incidence of chronic kidney disease among male adults: A prospective population-based study. Andrology 2019, 8, 575-582. [CrossRef] [PubMed]

131. Carrero, J.J.; Qureshi, A.R.; Parini, P.; Arver, S.; Lindholm, B.; Bárány, P.; Heimbürger, O.; Stenvinkel, P. Low Serum Testosterone Increases Mortality Risk among Male Dialysis Patients. J. Am. Soc. Nephrol. 2009, 20, 613-620. [CrossRef]

132. Shoskes, D.A.; Kerr, H.; Askar, M.; Goldfarb, D.A.; Schold, J. Low testosterone at time of transplantation is independently as-sociated with poor patient and graft survival in male renal transplant recipients. J. Urol. 2014, 192, 1168-1171. [CrossRef] [PubMed]

133. Soljancic, A.; Ruiz, A.L.; Chandrashekar, K.; Maranon, R.; Liu, R.; Reckelhoff, J.F.; Juncos, L.A. Protective role of testosterone in ischemia-reperfusion-induced acute kidney injury. Am. J. Physiol. Regul. Integr. Comp. Physiol. 2013, 304, R951-R958. [CrossRef] [PubMed]

134. Patil, C.N.; Wallace, K.; Lamarca, B.D.; Moulana, M.; Lopez-Ruiz, A.; Soljancic, A.; Juncos, L.A.; Grande, J.P.; Reckelhoff, J.F. Low-dose testosterone protects against renal ischemia-reperfusion injury by increasing renal IL-10-to-TNF- $\alpha$ ratio and attenuating T-cell infiltration. Am. J. Physiol. Physiol. 2016, 311, F395-F403. [CrossRef] [PubMed]

135. Kim, J.; Kil, I.S.; Seok, Y.M.; Yang, E.S.; Kim, D.K.; Lim, D.G.; Park, J.-W.; Bonventre, J.V.; Park, K.M. Orchiectomy attenuates post-ischemic oxidative stress and ischemia/reperfusion injury in mice. A role for manganese superoxide dismutase. J. Biol. Chem. 2006, 281, 20349-20356. [CrossRef]

136. Park, K.M.; Kim, J.I.; Ahn, Y.; Bonventre, A.J.; Bonventre, J.V. Testosterone Is Responsible for Enhanced Susceptibility of Males to Ischemic Renal Injury. J. Biol. Chem. 2004, 279, 52282-52292. [CrossRef]

137. Metcalfe, P.; Leslie, J.A.; Campbell, M.T.; Meldrum, D.R.; Hile, K.L.; Meldrum, K.K. Testosterone exacerbates obstructive renal injury by stimulating TNF- $\alpha$ production and increasing proapoptotic and profibrotic signaling. Am. J. Physiol. Metab. 2008, 294, E435-E443. [CrossRef] [PubMed]

138. Verzola, D.; Gandolfo, M.T.; Salvatore, F.; Villaggio, B.; Gianiorio, F.; Traverso, P.; Deferrari, G.; Garibotto, G. Testosterone promotes apoptotic damage in human renal tubular cells. Kidney Int. 2004, 65, 1252-1261. [CrossRef] [PubMed]

139. Abd El-Lateef, S.M.; El-Sayed, E.M.; Mansour, A.M.; Salama, S.A. The protective role of estrogen and its receptors in gentami-cininduced acute kidney injury in rats. Life Sci. 2019, 239, 117082. [CrossRef]

140. Ikeda, M.; Swide, T.; Vayl, A.; Lahm, T.; Anderson, S.; Hutchens, M.P. Estrogen administered after cardiac arrest and cardiopulmonary resuscitation ameliorates acute kidney injury in a sex- and age-specific manner. Crit. Care 2015, 19, 332. [CrossRef] [PubMed]

141. Wu, C.C.; Chang, C.Y.; Chang, S.T.; Chen, S.H. 17beta-Estradiol Accelerated Renal Tubule Regeneration in Male Rats After Is-chemia/Reperfusion-Induced Acute Kidney Injury. Shock 2016, 46, 158-163. [CrossRef] 
142. El-Gendy, A.A.; Elsaed, W.M.; Abdallah, H.I. Potential role of estradiol in ovariectomy-induced derangement of renal endo-crine functions. Ren. Fail. 2019, 41, 507-520. [CrossRef] [PubMed]

143. Elliot, S.; Berho, M.; Korach, K.; Doublier, S.; Lupia, E.; Striker, G.; Karl, M. Gender-specific effects of endogenous testosterone: Female $\alpha$-estrogen receptor-deficient C57Bl/6J mice develop glomerulosclerosis. Kidney Int. 2007, 72, 464-472. [CrossRef]

144. Doublier, S.; Lupia, E.; Catanuto, P.; Periera-Simon, S.; Xia, X.; Korach, K.; Berho, M.; Elliot, S.J.; Karl, M. Testosterone and 17beta-estradiol have opposite effects on podocyte apoptosis that precedes glomerulosclerosis in female estrogen receptor knockout mice. Kidney Int. 2011, 79, 404-413. [CrossRef]

145. Dixon, A.; Maric, C. 17beta-Estradiol attenuates diabetic kidney disease by regulating extracellular matrix and transforming growth factor-beta protein expression and signaling. Am. J. Physiol. Ren. Physiol. 2007, 293, F1678-F1690. [CrossRef]

146. Negulescu, O.; Bognar, I.; Lei, J.; Devarajan, P.; Silbiger, S.; Neugarten, J. Estradiol reverses TGF-beta1-induced mesangial cell apoptosis by a casein kinase 2-dependent mechanism. Kidney Int. 2002, 62, 1989-1998. [CrossRef] [PubMed]

147. Mankhey, R.W.; Wells, C.C.; Bhatti, F.; Maric, C. 17beta-Estradiol supplementation reduces tubulointerstitial fibrosis by in-creasing MMP activity in the diabetic kidney. Am. J. Physiol. Regul. Integr. Comp. Physiol. 2007, 292, R769-R777. [CrossRef]

148. Kummer, S.; Jeruschke, S.; Wegerich, L.V.; Peters, A.; Lehmann, P.; Seibt, A.; Mueller, F.; Koleganova, N.; Halbenz, E.; Schmitt, C.P.; et al. Estrogen receptor alpha expression in podocytes mediates protection against apoptosis in vitro and in vivo. PLoS ONE 2011, 6, e27457. [CrossRef]

149. Hutchens, M.P.; Fujiyoshi, T.; Komers, R.; Herson, P.S.; Anderson, S. Estrogen protects renal endothelial barrier function from ischemia-reperfusion in vitro and in vivo. Am. J. Physiol. Physiol. 2012, 303, F377-F385. [CrossRef]

150. Shibata, Y.; Takaoka, M.; Maekawa, D.; Kuwahara, C.; Matsumura, Y. Involvement of nitric oxide in the suppressive effect of 17beta-estradiol on endothelin-1 overproduction in ischemic acute renal failure. J. Cardiovasc. Pharmacol. 2004, 44, S459-S461. [CrossRef] [PubMed]

151. Satake, A.; Takaoka, M.; Nishikawa, M.; Yuba, M.; Shibata, Y.; Okumura, K.; Kitano, K.; Tsutsui, H.; Fujii, K.; Kobuchi, S.; et al. Protective effect of 17beta-estradiol on ischemic acute renal failure through the PI3K/Akt/eNOS pathway. Kidney Int. 2008, 73, 308-317. [CrossRef]

152. Zhao, X.; Huang, L.; Yin, Y.; Fang, Y.; Zhao, J.; Chen, J. Estrogen induces endothelial progenitor cells proliferation and mi-gration by estrogen receptors and PI3K-dependent pathways. Microvasc. Res. 2008, 75, 45-52. [CrossRef] [PubMed]

153. Singh, A.P.; Singh, N.; Pathak, D.; Bedi, P.M.S. Estradiol attenuates ischemia reperfusion-induced acute kidney injury through PPAR-gamma stimulated eNOS activation in rats. Mol. Cell. Biochem. 2019, 453, 1-9. [CrossRef]

154. Lakzaei, H.; Safari, T.; Komeili, G.R. Interaction of Sex Hormones and the Renin-Angiotensin System in Ovariectomized Rats Subjected to Ischemia-Reperfusion Induction. Adv. Biomed. Res. 2019, 8, 64. [CrossRef]

155. Nematbakhsh, M.; Nasri, H.; Talebi, A.; Pilehvarian, A.-A.; Safari, T.; Eshraghi-Jazi, F.; Haghighi, M.; Ashrafi, F.; Pezeshki, Z. Evidence against protective role of sex hormone estrogen in cisplatin-induced nephrotoxicity in ovarectomized rat model. Toxicol. Int. Former. Indian J. Toxicol. 2013, 20, 43-47. [CrossRef]

156. Müller, V.; Szabó, A.; Viklicky, O.; Gaul, I.; Pörtl, S.; Philipp, T.; Heemann, U.W. Sex hormones and gender-related differences: Their influence on chronic renal allograft rejection. Kidney Int. 1999, 55, 2011-2020. [CrossRef]

157. Antus, B.; Liu, S.; Yao, Y.; Zou, H.; Song, E.; Lutz, J.; Heemann, U. Effects of progesterone and selective oestrogen receptor modulators on chronic allograft nephropathy in rats. Nephrol. Dial. Transplant. 2004, 20, 329-335. [CrossRef]

158. Hughes, G.C.; Martin, D.; Zhang, K.; Hudkins, K.L.; Alpers, C.E.; Clark, E.A.; Elkon, K.B. Decrease in glomerulonephritis and Th1-associated autoantibody production after progesterone treatment in NZB/NZW mice. Arthritis Rheum. 2009, 60, 1775-1784. [CrossRef] [PubMed]

159. Sandhi, J.; Singh, J.P.; Kaur, T.; Ghuman, S.S.; Singh, A.P. Involvement of progesterone receptors in ascorbic acid-mediated protection against ischemia-reperfusion-induced acute kidney injury. J. Surg. Res. 2014, 187, 278-288. [CrossRef] [PubMed]

160. Freeman, M.E.; Kanyicska, B.; Lerant, A.; Nagy, G. Prolactin: Structure, Function, and Regulation of Secretion. Physiol. Rev. 2000, 80, 1523-1631. [CrossRef] [PubMed]

161. Pickford, G.E.; Phillips, J.G. Prolactin, a Factor in Promoting Survival of Hypophysectomized Killifish in Fresh Water. Science 1959, 130, 454-455. [CrossRef]

162. Lam, T. Prolactin and hydromineral regulation in fishes. Gen. Comp. Endocrinol. 1972, 3, 328-338. [CrossRef]

163. Loretz, C.A.; Bern, H.A. Prolactin and Osmoregulation in Vertebrates. Neuroendocrinology 1982, 35, 292-304. [CrossRef]

164. Sakai, Y.; Hiraoka, Y.; Ogawa, M.; Takeuchi, Y.; Aiso, S. The prolactin gene is expressed in the mouse kidney. Kidney Int. 1999, 55, 833-840. [CrossRef]

165. Mountjoy, K.; Cowden, E.A.; Dobbie, J.W.; Ratcliffe, J.G. Prolactin Receptors in the Rat Kidney. J. Endocrinol. 1980, 87, 47-54. [CrossRef]

166. Evan, A.P.; Palmer, G.C.; Lucci, M.S.; Solomon, S. Prolactin-induced stimulation of rat renal adenylate cyclase and autoradiographic localization to the distal nephron. Nephron 1977, 18, 266-276. [CrossRef] [PubMed]

167. Emmanouel, D.S.; Fang, V.S.; Katz, A.I. Prolactin metabolism in the rat: Role of the kidney in degradation of the hormone. Am. J. Physiol. Physiol. 1981, 240, F437-F445. [CrossRef] [PubMed]

168. Stier, C.T.; Cowden, E.A.; Friesen, H.G.; Allison, M.E.M. Prolactin and the Rat Kidney: A Clearance and Micropuncture Study. Endocrinology 1984, 115, 362-367. [CrossRef] 
169. Horrobin, D.; Lloyd, I.; Lipton, A.; Burstyn, P.; Durkin, N.; Muiruri, K. Actions of Prolactin on Human Renal Function. Lancet 1971, 298, 352-354. [CrossRef]

170. Lucci, M.S.; Bengele, H.H.; Solomon, S. Suppressive action of prolactin on renal response to volume expansion. Am. J. Physiol. Content 1975, 229, 81-85. [CrossRef]

171. Marshall, S.; Gelato, M.; Meites, J. Serum Prolactin Levels and Prolactin Binding Activity in Adrenals and Kidneys of Male Rats After Dehydration, Salt Loading, and Unilateral Nephrectomy. Exp. Biol. Med. 1975, 149, 185-188. [CrossRef] [PubMed]

172. Ibarra, F.; Crambert, S.; Eklöf, A.-C.; Lundquist, A.; Hansell, P.; Holtbäck, U. Prolactin, a natriuretic hormone, interacting with the renal dopamine system. Kidney Int. 2005, 68, 1700-1707. [CrossRef] [PubMed]

173. Crambert, S.; Sjöberg, A.; Eklöf, A.-C.; Ibarra, F.; Holtbäck, U. Prolactin and dopamine 1-like receptor interaction in renal proximal tubular cells. Am. J. Physiol. Physiol. 2010, 299, F49-F54. [CrossRef] [PubMed]

174. Marshall, S.; Kledzik, G.; Gelato, M.; Campbell, G.; Meites, J. Effects of estrogen and testosterone on specific prolactin binding in the kidneys and adrenals of rats. Steroids 1976, 27, 187-195. [CrossRef]

175. Morrissey, S.E.; Newth, T.; Rees, R.; Barr, A.; Shora, F.; Laycock, J.F. Renal effects of recombinant prolactin in anaesthetized rats. Eur. J. Endocrinol. 2001, 145, 65-71. [CrossRef]

176. Bussieres, L.; Laborde, K.; Dechaux, M.; Sachs, C. Effects of prolactin on Na-K-ATPase activity along the rat nephron. Pflügers Arch. Eur. J. Physiol. 1987, 409, 182-187. [CrossRef]

177. Rojas, L.; Reyes-Castro, L.A.; Ramírez, V.; Bautista-Pérez, R.; Rafael, C.; Castañeda-Bueno, M.; Meade, P.; Heros, P.D.L.; ArroyoGarza, I.; Bernard, V.; et al. Ovarian hormones and prolactin increase renal $\mathrm{NaCl}$ cotransporter phosphorylation. Am. J. Physiol. Physiol. 2015, 308, F799-F808. [CrossRef]

178. Handelsman, D.J. Hypothalamic-Pituitary Gonadal Dysfunction in Renal Failure, Dialysis and Renal Transplantation. Endocr. Rev. 1985, 6, 151-182. [CrossRef]

179. Cowden, E.A.; Ratcliffe, W.A.; Ratcliffe, J.G.; Dobbie, J.W.; Kennedy, A.C. Hyperprolactinaemia in Renal Disease. Clin. Endocrinol. 1978, 9, 241-248. [CrossRef]

180. Lo, J.C.; Beck, G.J.; Kaysen, G.A.; Chan, C.T.; Kliger, A.S.; Rocco, M.V.; Chertow, G.M.; for the FHN Study. Hyperprolactinemia in end-stage renal disease and effects of frequent hemodialysis. Hemodial. Int. 2017, 21, 190-196. [CrossRef]

181. Dobbie, J.; Mountjoy, K.; Cowden, E.; Allison, M.; Ratcliffe, J. Prolactin Status in Experimentally Induced Acute Renal Failure in the Rat. Nephron 1981, 27, 316-319. [CrossRef]

182. Falconer, I.R.; Vacek, A.T. Degradation of 125I-labelled prolactin in the rabbit: Effect of nephrectomy and prolactin infusion. J. Endocrinol. 1983, 99, 369-377. [CrossRef] [PubMed]

183. Sievertsen, G.D.; Lim, V.S.; Nakawatase, C.; Frohman, L.A. Metabolic Clearance and Secretion Rates of Human Prolactin in Normal Subjects and in Patients with Chronic Renal Failure. J. Clin. Endocrinol. Metab. 1980, 50, 846-852. [CrossRef] [PubMed]

184. Yavuz, D.G.; Topcu, G.; Ozener, C.; Akalin, S.; Sirikci, O. Macroprolactin does not contribute to elevated levels of prolactin in patients on renal replacement therapy. Clin. Endocrinol. 2005, 63, 520-524. [CrossRef] [PubMed]

185. Peces, R.; Horcajada, C.; López-Novoa, J.; Frutos, M.; Casado, S.; Hernando, L. Hyperprolactinemia in Chronic Renal Failure: Impaired Responsiveness to Stimulation and Suppression. Nephron 1981, 28, 11-16. [CrossRef] [PubMed]

186. Grzeszczak, W.; Kokot, F.; Wiecek, A.; Zukowska-Szczechowska, E. Prolactin secretion in kidney transplant patients. Int. Urol. Nephrol. 1990, 22, 567-571. [CrossRef]

187. Hou, S.H.; Grossman, S.; Molitch, M.E. Hyperprolactinemia in Patients with Renal Insufficiency and Chronic Renal Failure Requiring Hemodialysis or Chronic Ambulatory Peritoneal Dialysis. Am. J. Kidney Dis. 1985, 6, 245-249. [CrossRef]

188. Marshall, S.; Huang, H.H.; Kledzik, G.S.; Campbell, G.A.; Meites, J. Glucocorticoid Regulation of Prolactin Receptors in Kidneys and Adrenals of Male Rats. Endocrinology 1978, 102, 869-875. [CrossRef]

189. Carrero, J.J.; Kyriazis, J.; Sonmez, A.; Tzanakis, I.; Qureshi, A.R.; Stenvinkel, P.; Saglam, M.; Stylianou, K.; Yaman, H.; Taslipinar, A.; et al. Prolactin Levels, Endothelial Dysfunction, and the Risk of Cardiovascular Events and Mortality in Patients with CKD. Clin. J. Am. Soc. Nephrol. 2011, 7, 207-215. [CrossRef]

190. Reuwer, A.Q.; Nowak-Sliwinska, P.; Mans, L.A.; van der Loos, C.M.; von der Thusen, J.H.; Twickler, M.T.; Spek, C.A.; Goffin, V.; Griffioen, A.W.; Borensztajn, K.S. Functional consequences of prolactin signalling in endothelial cells: A potential link with angiogenesis in pathophysiology? J. Cell Mol. Med. 2012, 16, 2035-2048. [CrossRef]

191. Yang, X.; Meyer, K.; Friedl, A. STAT5 and prolactin participate in a positive autocrine feedback loop that promotes angiogenesis. J. Biol. Chem. 2013, 288, 21184-21196. [CrossRef]

192. Triebel, J.; Bertsch, T.; Bollheimer, C.; Rios-Barrera, D.; Pearce, C.F.; Hüfner, M.; De La Escalera, G.M.; Clapp, C. Principles of the prolactin/vasoinhibin axis. Am. J. Physiol. Integr. Comp. Physiol. 2015, 309, R1193-R1203. [CrossRef]

193. González, C.; Rosas-Hernández, H.; Jurado-Manzano, B.; Ramirez-Lee, M.A.; Salazar-García, S.; Martinez-Cuevas, P.P.; VelardeSalcedo, A.J.; Morales-Loredo, H.; Espinosa-Tanguma, R.; Ali, S.F.; et al. The prolactin family hormones regulate vascular tone through NO and prostacyclin production in isolated rat aortic rings. Acta Pharmacol. Sin. 2015, 36, 572-586. [CrossRef] [PubMed]

194. Goldhar, A.S.; Vonderhaar, B.K.; Trott, J.F.; Hovey, R.C. Prolactin-induced expression of vascular endothelial growth factor via Egr-1. Mol. Cell. Endocrinol. 2005, 232, 9-19. [CrossRef] [PubMed]

195. Clapp, C.; Aranda, J.; Gonzalez, C.; Jeziorski, M.C.; Martinez de la Escalera, G. Vasoinhibins: Endogenous regulators of angiogenesis and vascular function. Trends Endocrinol. Metab. 2006, 17, 301-307. [CrossRef] [PubMed] 
196. Piwnica, D.; Touraine, P.; Struman, I.; Tabruyn, S.; Bolbach, G.; Clapp, C.; Martial, J.A.; Kelly, P.A.; Goffin, V. Cathepsin D Processes Human Prolactin into Multiple 16K-Like N-Terminal Fragments: Study of Their Antiangiogenic Properties and Physiological Relevance. Mol. Endocrinol. 2004, 18, 2522-2542. [CrossRef]

197. Clapp, C.; Martial, J.A.; Guzman, R.C.; Rentier-Delure, F.; Weiner, R.I. The 16-kilodalton N-terminal fragment of human prolactin is a potent inhibitor of angiogenesis. Endocrinology 1993, 133, 1292-1299. [CrossRef]

198. D'Angelo, G.; Struman, I.; Martial, J.; Weiner, R.I. Activation of mitogen-activated protein kinases by vascular endothelial growth factor and basic fibroblast growth factor in capillary endothelial cells is inhibited by the antiangiogenic factor 16-kDa N-terminal fragment of prolactin. Proc. Natl. Acad. Sci. USA 1995, 92, 6374-6378. [CrossRef]

199. Lee, S.-H.; Kunz, J.; Lin, S.-H.; Yu-Lee, L.-Y. 16-kDa Prolactin Inhibits Endothelial Cell Migration by Down-Regulating the Ras-Tiam1-Rac1-Pak1 Signaling Pathway. Cancer Res. 2007, 67, 11045-11053. [CrossRef]

200. Martini, J.F.; Piot, C.; Humeau, L.M.; Struman, I.; Martial, J.A.; Weiner, R.I. The antiangiogenic factor 16K PRL induces programmed cell death in endothelial cells by caspase activation. Mol. Endocrinol. 2000, 14, 1536-1549. [CrossRef]

201. Gonzalez, C.; Corbacho, A.M.; Eiserich, J.P.; Garcia, C.; Lopez-Barrera, F.; Morales-Tlalpan, V.; Barajas-Espinosa, A.; Diaz-Muñoz, M.; Rubio, R.; Lin, S.H.; et al. 16K-prolactin inhibits activation of endothelial nitric oxide synthase, intracellular calcium mobilization, and endothelium-dependent vasorelaxation. Endocrinology 2004, 145, 5714-5722. [CrossRef]

202. Garcia, C.; Nunez-Anita, R.E.; Thebault, S.; Arredondo Zamarripa, D.; Jeziorsky, M.C.; Martinez de la Escalera, G.; Clapp, C. Requirement of phosphorylatable endothelial nitric oxide synthase at Ser-1177 for vasoinhibin-mediated inhibition of endothelial cell migration and proliferation in vitro. Endocrine 2014, 45, 263-270. [CrossRef] [PubMed]

203. Baldocchi, R.A.; Tan, L.; Nicoll, C.S. Processing of rat prolactin by rat tissue explants and serum in vitro. Endocrinology 1992, 130, 1653-1659. [CrossRef]

204. Clapp, C.; Sears, P.S.; Nicoll, C.S. Binding Studies with Intact Rat Prolactin and a 16K Fragment of the Hormone. Endocrinology 1989, 125, 1054-1059. [CrossRef]

205. Leaños-Miranda, A.; Márquez-Acosta, J.; Cárdenas-Mondragón, G.M.; Chinolla-Arellano, Z.L.; Rivera-Leaños, R.; BermejoHuerta, S.; Romero-Arauz, J.F.; Alvarez-Jiménez, G.; Ramos-León, J.C.; Ulloa-Aguirre, A. Urinary Prolactin as a Reliable Marker for Preeclampsia, Its Severity, and the Occurrence of Adverse Pregnancy Outcomes. J. Clin. Endocrinol. Metab. 2008, 93, 2492-2499. [CrossRef]

206. Jourde-Chiche, N.; Fakhouri, F.; Dou, L.; Bellien, J.; Burtey, S.; Frimat, M.; Jarrot, P.-A.; Kaplanski, G.; Le Quintrec, M.; Pernin, V.; et al. Endothelium structure and function in kidney health and disease. Nat. Rev. Nephrol. 2019, 15, 87-108. [CrossRef]

207. González, C.; Parra, A.; Ramírez-Peredo, J.; Garcia, C.; Rivera, J.C.; Macotela, Y.; Aranda, J.; Lemini, M.; Arias, J.; Ibargüengoitia, F.; et al. Elevated vasoinhibins may contribute to endothelial cell dysfunction and low birth weight in preeclampsia. Lab. Investig. 2007, 87, 1009-1017. [CrossRef]

208. Cruz, M.; Cosío, G.; Jeziorski, M.C.; Vargas-Barroso, V.; Aguilar, M.B.; Cárabez, A.; Berger, P.; Saftig, P.; Arnold, E.; Thebault, S.; et al. Cathepsin D Is the Primary Protease for the Generation of Adenohypophyseal Vasoinhibins: Cleavage Occurs within the Prolactin Secretory Granules. Endocrinology 2009, 150, 5446-5454. [CrossRef]

209. Lkhider, M.; Castino, R.; Bouguyon, E.; Isidoro, C.; Ollivier-Bousquet, M. Cathepsin D released by lactating rat mammary epithelial cells is involved in prolactin cleavage under physiological conditions. J. Cell Sci. 2004, 117, 5155-5164. [CrossRef] [PubMed]

210. Ozkayar, N.; Piskinpasa, S.; Akyel, F.; Turgut, D.; Bulut, M.; Turhan, T.; Dede, F. Relation between serum cathepsin D levels and endothelial dysfunction in patients with chronic kidney disease. Nefrologia 2015, 35, 72-79. [CrossRef] [PubMed]

211. Fox, C.; Cocchiaro, P.; Oakley, F.; Howarth, R.; Callaghan, K.; Leslie, J.; Luli, S.; Wood, K.M.; Genovese, F.; Sheerin, N.S.; et al. Inhibition of lysosomal protease cathepsin D reduces renal fibrosis in murine chronic kidney disease. Sci. Rep. 2016, 6, 20101. [CrossRef]

212. Cocchiaro, P.; Fox, C.; Tregidgo, N.W.; Howarth, R.; Wood, K.M.; Situmorang, G.R.; Pavone, L.M.; Sheerin, N.S.; Moles, A. Lysosomal protease cathepsin D; a new driver of apoptosis during acute kidney injury. Sci. Rep. 2016, 6, 27112. [CrossRef]

213. Suzuki, C.; Tanida, I.; Ohmuraya, M.; Trejo, J.A.O.; Kakuta, S.; Sunabori, T.; Uchiyama, Y. Lack of Cathepsin D in the Renal Proximal Tubular Cells Resulted in Increased Sensitivity against Renal Ischemia/Reperfusion Injury. Int. J. Mol. Sci. 2019, 20, 1711. [CrossRef]

214. Yamamoto-Nonaka, K.; Koike, M.; Asanuma, K.; Takagi, M.; Trejo, J.A.O.; Seki, T.; Hidaka, T.; Ichimura, K.; Sakai, T.; Tada, N.; et al. Cathepsin D in Podocytes Is Important in the Pathogenesis of Proteinuria and CKD. J. Am. Soc. Nephrol. 2016, 27, 2685-2700. [CrossRef] [PubMed]

215. Moulton, B.C.; Khan, S. Progestin and Estrogen Control of Cathepsin D Expression and Processing in Rat Uterine Luminal Epithelium and Stroma-Myometrium. Exp. Biol. Med. 1992, 201, 98-105. [CrossRef] [PubMed]

216. Elangovan, S.; Moulton, B.C. Progesterone and estrogen control of rates of synthesis of uterine cathepsin D. J. Biol. Chem. 1980, 255, 7474-7479. [CrossRef]

217. Li, S.A.; Liao, D.Z.; Yazlovitskaya, E.M.; Pantazis, C.G.; Li, J.J. Induction of cathepsin D protein during estrogen carcinogenesis: Possible role in estrogen-mediated kidney tubular cell damage. Carcinog 1997, 18, 1375-1380. [CrossRef]

218. Augereau, P.; Miralles, F.; Cavailles, V.; Gaudelet, C.; Parker, M.; Rochefort, H. Characterization of the proximal estro-genresponsive element of human cathepsin D gene. Mol. Endocrinol. 1994, 8, 693-703. 